\title{
Effect of Garlic (Allium sativum L.) Additive on Nutrient and Aflatoxin Contents of 'Kulikuli' from Northern Nigeria
}

Nanamaymuna Bola Abdul-Lateef ${ }^{1}$, Gbolagade Segun Jonathan ${ }^{1 *}$, John Chikwem ${ }^{2}$, Adebola Odeseye ${ }^{3}$, Michael Dare Asemoloye $^{3}$

${ }^{1}$ Mycology \& Applied Microbiology Group, Department of Botany, University of Ibadan, Ibadan, Nigeria

${ }^{2}$ Department of Biology, 1570 Baltimore Pike, Pennsylvania, USA.

${ }^{3}$ School of Pharmaceutical Sciences and Technology (Health Science Platform), Tianjin University, Tianjin, China.

DOI: $10.36347 / \mathrm{sajb} .2020 . v 08 \mathrm{i09.002}$

| Received: 06.08.2020 | Accepted: 13.09.2020 | Published: 25.09.2020

*Corresponding author: Gbolagade Segun Jonathan

Abstract

Original Research Article

Contamination of food and food products by aflatoxin has raised a lot of food safety concerns. This present study investigates the influence of garlic (Allium sativum) on the nutrient and aflatoxin contents, as well as associated toxigenic fungi in 'kulikuli' (groundnut cake). Samples of kulikuli (a common convenience food) from Nigeria were purchased from five markets in five different towns in North-West (NW) and North-Central (NC) Nigeria. Samples of this snack were also prepared in the Mycology Laboratory of the University of Ibadan. Kulikuli with garlic (BUIKG) and without garlic (BUIK) served as controls. Fungi associated with this food samples were isolated, characterized and subjected to percentage incidence test. Nutrient composition of kulikuli such as Crude Protein, Fibre, Fat, Moisture and Ash contents were determined. Aflatoxins $\left(\mathrm{AFB}_{1}, \mathrm{AFB}_{2}, \mathrm{AFG}_{1}\right.$ and $\left.\mathrm{AFG}_{2}\right)$ contents as well as $\mathrm{pH}$ were also determined in kulikuli using standard procedures. Aspergillus flavus and A. parasiticus had the highest incidence of $26.59 \%$ and $26.08 \%$ respectively. Aspergillus fumigatus $(2.83 \%)$ had the least while BUIKG had no fungal incidence. Kulikuli samples from markets were significantly different $\left(\alpha_{0.05}\right)$ in nutrients. Moisture contents ranged between 8.88 and $11.91 \%$, ash $(2.89-3.91 \%)$, crude protein $(43.18-49.23 \%)$, fibre $(2.99-3.20 \%)$ and fat $(3.88-4.83 \%)$. BUIKG kulikuli had the highest crude protein $(59.23 \%)$, fibre $(4.55 \%)$ and $\mathrm{pH}(6.88)$. The BUIK had the highest fat $(3.82 \%)$ and moisture content $(12.61 \%)$, while both BUIK and BUIKG had highest ash content $(4.84 \%)$. The market purchased kulikuli samples had the highest $\mathrm{AFB}_{1}, \mathrm{AFB}_{2}, \mathrm{AFG}_{1}$ and $\mathrm{AFG}_{2}$ of $1.58,2.72,0.14$ and $0.20 \mu \mathrm{g} / \mathrm{kg}$ respectively, while the laboratory prepared (BUIKG) had the least $\mathrm{AFB}_{1}(0.34 \mu \mathrm{g} / \mathrm{kg}), \mathrm{AFB}_{2}(0.37 \mu \mathrm{g} / \mathrm{kg}), \mathrm{AFG}_{1}(0.01 \mu \mathrm{g} / \mathrm{kg})$ and $\mathrm{AFG} 2$ $(0.02 \mu \mathrm{g} / \mathrm{kg})$. It was observed that the introduction of garlic into kulikuli significantly reduced fungal contamination and aflatoxin level in the different samples. The implications of these results are discussed.

Keywords: Mycotoxins, Groundnut, fungi, Food values, Analysis.

Copyright @ 2020: This is an open-access article distributed under the terms of the Creative Commons Attribution license which permits unrestricted use, distribution, and reproduction in any medium for non-commercial use (NonCommercial, or CC-BY-NC) provided the original author and source are credited

\section{INTRODUCTION}

Mycotoxins (fungal toxins) have been implicated as major carcinogenic and mutagenic agents. These fungal toxins could cause liver and kidney diseases which could lead to untimely death in man $[1$, 2]. Aflatoxins are the most abundant mycotoxins produced by members of Aspergillus especially, $A$. flavus and A. parasiticus. They are of different types: aflatoxin $\mathrm{B}_{1}\left(\mathrm{AFB}_{1}\right), \mathrm{B}_{2}\left(\mathrm{AFB}_{2}\right), \mathrm{G}_{1}\left(\mathrm{AFG}_{1}\right), \mathrm{G}_{2}\left(\mathrm{AFG}_{2}\right)$, $\mathrm{M}_{1}\left(\mathrm{AFM}_{1}\right), \mathrm{M}_{2}\left(\mathrm{AFM}_{2}\right), \mathrm{RM}(\mathrm{AFRM}), \mathrm{d}_{1}\left(\mathrm{AFd}_{1}\right), \mathrm{R}_{\mathrm{o}}$ $\left(\mathrm{AFR}_{\mathrm{o}}\right)$ and so on $[3,4]$. Unfortunately, most aflatoxin incidences are reported from the developing countries due to poor infrastructures and public quality control of stored foodstuffs [5]. In Nigeria, reports have affirmed the presence of aflatoxin in maize, rice, guinea corn, sorghum, cocoa, cocoa-based beverages, peanut and groundnuts $[6,7,2,8]$. The contamination of these food products has raised a lot of food safety concerns; since in most cases, these foods are not consumed in their original state; rather, they are further processed into indigenous foods such as ogi, eko, tuwo, kunu, donkwa, and masa among others. Groundnuts are further processed to kulikuli, omisagwe, candy, groundnut butter, chili, etc $[9,2,5]$.

Groundnut (Arachis hypogaea L.) is one of the common foods which can be easily contaminated by mycotoxigenic fungi. Groundnut contains numerous vital nutrients which could enhance the growth of various microorganisms including fungi $[10,11]$. Chemically, it is composed of protein, amino and fatty acids [12]. Because of its nutrient composition, 
groundnut may be prone to fungi and mycotoxin contamination.

Groundnut, be it raw, boiled (epa sise, daffafiyar gyada), cake (kulikuli), roasted (epa yiyan, marao marao, tupus), candy and ball is often hawked as a snack in rural areas of Nigeria [13,2]. One of the most prominent Nigerian snack from groundnut is kulikuli which is the fried residue obtained from groundnut extraction $[14,9]$. It is rich in protein and crude fat. It can be eaten alone or with garri, or as a supplement to koko, fura and akamu. Also, kulikuli can be further processed through grinding, and used in local Hausa cuisines such as gurasa, suya, dambu, kwaddo and kilishi $[15,16]$.

Although kulikuli is popularly consumed across West African countries, there are very few data currently available on this food material in terms of its safety and nutritional attributes. Interestingly, majority of the available data originated from Nigeria, and have focused on the microbiological quality and nutritional values.

Many strategies have been developed for the control of aflatoxigenic fungi in foods; and in recent times, garlic (Allium sativum L.) has been frequently used in controlling infectious agents as well as microbial load in food items [17]. Garlic was used for medicine and food as evidenced by ancient writings from China Egypt, Greece, and India [18]. Epidemiological studies have also shown that enhanced dietary intake of garlic could reduce the incidence of various types of human diseases, particularly cancer of the stomach, colon, breast and prostate [19]. This study investigated the incidence of toxigenic fungi, their prevention, aflatoxin contamination and proximate compositions of kulikuli collected from selected states in Northern Nigeria.

\section{MATERIALS AND METHODS Collection of Samples}

Samples of kulikuli (Fig. 1) were purchased from 25 different markets in 5 states of Northern Nigeria (Table 1). The locations covered were within two (2) geo-political zones in Northern Nigeria, namely Northwest (NW) and North Central (NC). The North-Western States occupy $80 \%$ of the sampled state with North central occupying only $20 \%$ of the sampled states.

Geographically, the North-Western states include Kano (total landmass of $20,131 \mathrm{~km}^{2}$ and lies within latitude $11^{\circ} 30^{\prime} \mathrm{N}$ and longitudes $8^{\circ} 30^{\prime} \mathrm{E}$ ); Kaduna (total landmass of $46,053 \mathrm{~km}^{2}$ or $17,781 \mathrm{sq}$. miles and lies within latitude $10^{\circ} 20^{\prime} \mathrm{N}$ and longitude $7^{\circ} 45^{\prime} \mathrm{E}$ ); Zamfara (total landmass of $39,762 \mathrm{~km}^{2}$ or 15,352 sq. miles and lies within latitude $12^{\circ} 10^{\prime} \mathrm{N}$ and longitude

Table-1: Groundnut cake (Kulikuli) samples collected from 5 states in Nigeria

\begin{tabular}{|l|l|l|l|} 
GPZ & States & Markets & Sample \\
\hline
\end{tabular}

\begin{tabular}{|c|c|c|c|}
\hline NW & Kano & $\begin{array}{ll}\text { Rimin Gado } & \\
\text { Janguza } & \\
\text { Kurmi } & \\
\text { Sabongari } & \\
\text { Rimi } & \text { Total }\end{array}$ & $\begin{array}{l}1 \\
1 \\
1 \\
1 \\
1 \\
5\end{array}$ \\
\hline NW & Zamfara & $\begin{array}{l}\text { Bungudu } \\
\text { Tsohuwar Kasuwa } \\
\text { Dampa } \\
\text { Sabuwar Kasuwa } \\
\text { Tudun Wada } \\
\text { Total }\end{array}$ & $\begin{array}{l}1 \\
1 \\
1 \\
1 \\
1 \\
5\end{array}$ \\
\hline NW & Kaduna & $\begin{array}{l}\text { Bacci } \\
\text { Kaduna Central } \\
\text { Kawo } \\
\text { Sabuwar Gari } \\
\text { Kakuri Total }\end{array}$ & $\begin{array}{l}1 \\
1 \\
1 \\
1 \\
1 \\
5\end{array}$ \\
\hline NW & Sokoto & $\begin{array}{l}\text { Kanawa } \\
\text { Ilaela } \\
\text { Dange Shuni } \\
\text { Jabo } \\
\text { Yan tumatir } \\
\quad \text { Total }\end{array}$ & $\begin{array}{l}1 \\
1 \\
1 \\
1 \\
1 \\
5\end{array}$ \\
\hline $\mathrm{NC}$ & Abuja-FCT & $\begin{array}{l}\text { Utako } \\
\text { Wuse } \\
\text { Madalla } \\
\text { Dutse } \\
\text { Bwari } \quad \text { Total }\end{array}$ & $\begin{array}{l}1 \\
1 \\
1 \\
1 \\
1 \\
5\end{array}$ \\
\hline & & TOTAL & 25 \\
\hline
\end{tabular}

$N W=$ North West $;$ NC $=$ North Central

$6^{\circ} 15^{\prime} \mathrm{E}$ ); and Sokoto (total landmass of 25,973 $\mathrm{km}^{2}$ or $10,028 \mathrm{sq}$. miles and lies within latitude $13^{\circ} 05^{\prime} \mathrm{N}$ and longitude $05^{\circ} 15^{\prime} \mathrm{E}$ ) while the North central state sampled was only Abuja-FCT (total landmass of 7,315 $\mathrm{km}^{2}$ or 2,824 sq. miles)

\section{Production of Kulikuli and Garlic Additive}

Kulikuli samples (Fig. 1) were also prepared under aseptic laboratory conditions at the Mycology Laboratory in the Department of Botany, University of Ibadan. The laboratory samples were prepared in two groups viz:

I. University of Ibadan Kulikuli with garlic additive (BUIKG).

II. University of Ibadan Kulikuli without garlic additive (BUIK).

Garlic was supplemented at $0.05 \mathrm{~g} / 100 \mathrm{mg}$ of milled groundnut in the BUIK following the recommendation of the European Union on the addition of spices in foods. 


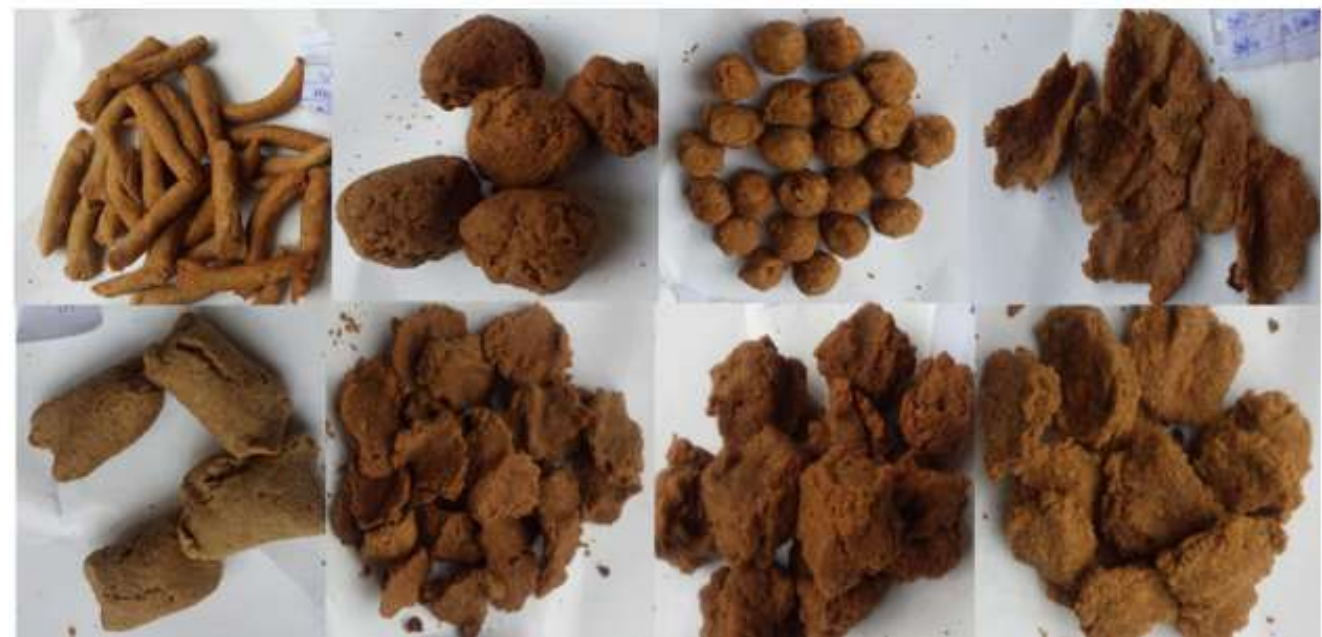

Fig-1: Different types of kulikuli) samples

\section{Nutrient Analysis of the kulikuli Samples}

The collected kulikuli samples were analyzed chemically according to the Official Methods of Analyses described by the Association of Official Chemists [20]. All analysis was carried out in triplicates.

\section{Crude Protein}

Crude Protein was determined by the routine semi-micro kieldahl procedure. This procedure consisted of three techniques namely: Digestion, Distillation and Titration. Kjedahl digestion was done using $0.5 \mathrm{~g}$ each of well-ground dried sample to which $10 \mathrm{ml}$ of conc. $\mathrm{H}_{2} \mathrm{SO}_{4}$ was added before the tube was placed into the appropriate well of the digestion block heater in a fume cupboard. The digestion proceeded for 4 hours, after which a clear colorless solution was left in the tube. The content of the tube was cooled and carefully transferred into $100 \mathrm{ml}$ volumetric flask, thoroughly rinsing the digestion tube with distilled water; and the flask was made up to $100 \mathrm{ml}$ with distilled water.

The distillation was carried out using Markham distillation apparatus; and all precautions were taken to avoid any form of leakage. Steam generator was placed on a heating mantle for 10 minutes at $100^{\circ} \mathrm{C}$. The steam generator was then removed from the heat source to allow the developing vacuum to remove condensed water. Five milliliters $(5 \mathrm{ml})$ of the digest was pipetted into this apparatus via the small funnel aperture. To this was also added $5 \mathrm{ml}$ of $40 \%(\mathrm{w} / \mathrm{v}) \mathrm{NaOH}$. The mixture was steam distilled for 2 mins and transferred into a $50 \mathrm{ml}$ conical flask containing $10 \mathrm{ml}$ of $2 \%$ boric acid. Methyl red indicator $(0.2 \mathrm{ml})$ was added and the solution changed color from red to green showing that all the ammonia liberated have been trapped. The green colored solution obtained was then titrated against) $0.01 \mathrm{M}$ $\mathrm{NaOH}$ in a $50 \mathrm{ml}$ burette. At the end point, the green color turned to wine color indicating that all the nitrogen trapped as ammonium borate $\left(\left(\mathrm{NH}_{4}\right)_{2} \mathrm{BO}_{3}\right)$ has been removed as ammonium chloride $\left(\mathrm{NH}_{4} \mathrm{Cl}\right)$ [21]

The percentage Nitrogen in this analysis was calculated using formula:

$\% \mathrm{~N}=$ Titre value $\mathrm{x}$ Atomic mass of Nitrogen $\mathrm{x}$ Molarity of HCL used x 4

\section{Crude Fat}

Crude Fat was determined using $1.0 \mathrm{~g}$ each of the dried samples in a fat free extraction thimble which was lightly plugged with cotton wool. The thimble was placed in the extractor and fitted with a reflux condenser. A Soxhlet flask $(250 \mathrm{ml})$ which had been previously dried in an oven, cooled in a desiccator and weighed was filled to $3 / 4$ of its volume with petroleum ether $\left(40^{\circ}-60^{\circ} \mathrm{C}\right.$ boiling point). Extractor and condenser set were placed on the heater which was left for 6 hours with constant running water for condensation of ether vapor. The ether was left to siphon for 10-12 times until it was short of siphoning. Thereafter, ether content of the extractor was carefully drained into the ether stock bottle. The thimble containing each sample was then removed and dried. The extractor, flask and condenser were replaced and the distillation continued until the flask was practically dry. The flask which contained the fat was detached, its exterior cleaned and dried to constant weight in the oven at $55^{\circ} \mathrm{C}$. If the initial weight of dry Soxhlet flask is $\mathrm{W}_{0}$ and the final weight of oven dried flask + oil/fat is $\mathrm{W}_{1}$, percentage fat was obtained by the formula:

$$
\mathrm{W}_{1}-\mathrm{W}_{0} \times 100 / 1 \mathrm{Wt} \text { of sample taken }
$$

\section{Moisture Content}

This was determined using $2.0 \mathrm{~g}$ of the sample in a previously weighed crucible. The crucible with the sample was then placed into an oven set at $100^{\circ} \mathrm{C}$ to dry 
to a constant weight for 24 hours. The crucible with the sample was removed from the oven and transferred to a desiccator, cooled for ten minutes and weighed. If the weight of sampled crucible is $\mathrm{W}_{0}$; weight of crucible plus sample is $\mathrm{W}_{1}$; Weight of crucible plus oven dried sample is $\mathrm{W}_{3}$; then:

$\%$ moisture $=\mathrm{W} 2-\mathrm{W} 3 / \mathrm{W} 2-\mathrm{W} 1 \quad x \frac{100}{1}$

$\mathrm{W} 1$ = weight of container with lid; W2 = weight of container with lid and sample before drying; and W3 = weight of container with lid and sample after drying

\section{Ash content determination}

Two grams $(2.0 \mathrm{~g})$ of the sample was placed into a porcelain crucible. This was transferred into a muffle furnace set at $55^{\circ} \mathrm{C}$ and left for about 4 hours. About this time, the sample turned to white ash. The crucible and its contents were cooled at room temperature in a desiccator and weighed. This was done in triplicates. The percentage ash was calculated from the formula below

$$
\% \text { Ash content }=\frac{\text { wt of ash }}{\text { Original weight of sample }} \times \frac{100}{1}
$$

\section{Crude Fibre}

Crude Fibre was determined using $2.0 \mathrm{~g}$ of the sample in a fibre flask in which $0.255 \mathrm{~N}$ Sulphuric acid $\left(\mathrm{H}_{2} \mathrm{SO}_{4}\right)$ was added. The mixture was heated under the reflux for 1 hour with the heating mantle. The hot mixture was filtered through a fibre sieve cloth. The fluid obtained was discarded and the residue was returned to the fibre flask to which $100 \mathrm{ml}$ of $0.313 \mathrm{~N}$ sodium hydroxide solutions $(\mathrm{NaOH})$ was added and heated under reflux for another 1 hour. The mixture was filtered through a fibre sieve cloth and $10 \mathrm{ml}$ of acetone was added to dissolve any organic constituent. The residue was washed twice with $50 \mathrm{ml}$ hot water on the sieve cloth before it was finally transferred into the crucible. The crucible and the residue was oven-dried at $100^{\circ} \mathrm{C}$ overnight to drive off moisture. The oven-dried crucible containing the residue was cooled in a desiccator and later weighed to obtain the weight $\mathrm{W}_{1}$. The crucible with weight $\mathrm{W}_{1}$ was transferred to the muffle furnace for ashing at $550^{\circ} \mathrm{C}$ for 4 hours. The crucible containing white or grey Ash (free of carbonaceous material) was cooled in the desiccator and weighed to obtain $\mathrm{W}_{2}$. The difference $\mathrm{W}_{1}-\mathrm{W}_{2}$ gave the weight of fibre. The percentage fibre was obtained by the formula:

$$
\% \text { fibre }=\frac{W_{1}-W_{2}}{w t \text { of sample }} \times \frac{100}{1}
$$

pH

$\mathrm{pH}$ was determined with a $\mathrm{pH}$ meter. Ten grams $(10.0 \mathrm{~g})$ of each sample were homogenized in $50.0 \mathrm{ml}$ of distilled water. The resulting suspensions were decanted and their $\mathrm{pH}$ was measured. The $\mathrm{pH}$ meter was standardized using a standard buffer of $\mathrm{pH} 4.0$ and sterilized water.

\section{Sample Preparation and Fungal Isolation}

Kulikuli samples were surface sterilized with sterile cotton wool that was soaked with $95 \%$ ethanol. Potato Dextrose Agar (Oxoid) plates were aseptically prepared using standard methods [21, 22]. Streptomycin sulphate $(0.05 \mathrm{mg} / \mathrm{L})$ was added to the agar after sterilization to prevent bacterial growth. Kulikuli samples were inoculated into the plates in triplicates before incubation at $30 \pm 2{ }^{\circ} \mathrm{C}$ for 5-7 days [22, 23]. Fungal growths were sub-cultured to obtain pure cultures. Each fungal isolate was mounted on a microscope slide with few drops of lactophenol cotton blue for microscopic study [21].

Incidence of each fungus was calculated in percentages across each state to determine the dominant fungus associated with kulikuli in each state (equation 1).

$$
\text { Percentage incidence }=\frac{\text { Number of a particular fungal specie }}{\text { Total Number of fungal species }} \times 100
$$

\section{Identification of the Isolated Fungal Strains}

This was done using the growth and morphological characteristics of the isolated fungal strains; the fungi were checked for their characteristic features such as colony size and shape, surface feature on plate and underside such as colonial appearance, color, texture, growth pattern; and microscopic features such as conidia, sporangium and hyphae arrangements; and these were also compared with those of already identified fungal strains. The fungal strains were prepared and characterized using the procedures of Jonathan and Olowolafe [22].

\section{Aflatoxin Analysis of Samples}

This was carried out using high performance liquid chromatography (HPLC) method as described by Oluwafemi and Ibeh [24], and Jonathan et al. [23]. The used HPLC machine comprised of LDC, Milton Roy Constametric pump and a Lichrosorb RP-18 column (Merck Hibar). It has a particle size of $5 \mu \mathrm{m}$, length of $125 \mathrm{~mm}$ with inside diameter of $4 \mathrm{~mm}$. It has a $60 \mathrm{MPa}$ pump pressure and automatic type injector (Rheotype Gilson Abimed Model 231). The detector has a 535 fluorescence spectrophotometer gamma excitation 365 $\mathrm{mm}$, and gamma emission $444 \mathrm{~nm}$ ) and the flow rate was $1 \mathrm{~mL}$ per minute and the injection volume was $50 \mu \mathrm{L}$ with the use of mobile phase containing water/acetonitrile (75: 25) with flow rate $1.2 \mathrm{~mL} \mathrm{min-1}$ for $20 \mathrm{~min}$. 40 grams of each kulikuli sample was defatted using Soxhlet-type extractor solvent N-hexene; 
the defatted residue was extracted with ethyl acetate (three times, $50 \mathrm{~mL} / \mathrm{each}$ ). The extracts were combined and dried using anhydrous sodium sulphate, and concentrated under vacuum to near dryness; this was transferred into brown glass vial, and evaporated under nitrogen stream. For cleaning up, the crude extract was suspended in $1 \mathrm{~mL}$ chloroform and applied to $14 \times 0.8$ cm column containing 2.5 Kiesel gel 60 and 70/230 silica gel. The aflatoxin analysis was done using Lichrosorb RP-18 column; the quantitative determination of the aflatoxins was carried out using aflatoxin standards (Sigma).

\section{STATISTICAL DATA ANALYSIS}

The quantitative data obtained were analyzed using statistical Package for Social Sciences (SPSS Version 22) and Microsoft Excel 2016. Means, standard deviation, variance and range were separated using mean comparison technique; and tests for significance by Analysis of Variance (ANOVA) at $\mathrm{p}=0.05$.

\section{RESULTS}

\section{Prevalence of Fungi in the Groundnut cake (Kulikuli) Samples}

Forty eight (48) fungal strains were isolated from the test kulikuli samples. They were from 9 species of fungi (Aspergillus flavus, Aspergillus parasiticus, Aspergillus tamarii, Penicillium oxalicum, Fusarium oxysporum, Penicillium chrysogenum, Aspergillus niger, Fusarium compaticum and Aspergillus fumigatus).

Aspergillus niger was characterized with black-brown mycelium and greenish-yellow to yellow orange coloration at the plate reverse side, a glubose head splitting with age; it has long, closely packed and brownish metulae. A. tamari showed a rusty-brown colony on plate and creamish-brown at reverse with long and rough stripe; its head was partly globular with thick orange yellow conidia which are strongly roughened. $A$. flavus was distinguished with yellowish-green becoming green with age coloration on plate; creamish-yellow on reverse side. It has radiating head which becomes loosely columnar with age and a long, verrucose and hyaline stripe with small metulae. Similarly, $A$. fumigatus had 3.0 to $3.2 \mathrm{~cm}$ growth diameter on plate with bluish-green on plate and creamish-yellow in its reverse; its head was columnar in shape, short, smooth and greenish-grey stipe; metulae was absent and its philades was ampuliform, closely packed, roughly parallel to the axis of the stipe. It also has flobose, echiniate and greenish conidia. A. parasiticus also had light sparse grey green to pale blue green or parrot green, mycelium with fluffy creamy white to dull white color and exudates are present on surface; reverse uncolored to yellowish or orange wrinkled mycelia growth; it has very few sclerotia in wheat brown color. Conidia was very sparse in dull blue green color, reverse yellowish orange to light peach.

Penicillium chrysogenum was characterized by its 2.7 to $4.5 \mathrm{~cm}$ colony diameter on plate; the texture was sulcate and velutinous. It has a short, smooth stipe. The penicillin was tervenicillate, philades ampulliform, collula very short, both divergent and appressed branches. The conidia were ellipsoidal to spherical, smooth and greenish. Penicillium oxalicum was characterized by velutinous texture and heavy sporulation with grayish-green upper and pale yellow reverse plate color. It has long and smooth long stipe, and with asymmetrically bivaricilliate metulae that was closely oppressed. Phialides was accrose with a very short collula. The conidia were ellipsoidal, large, smooth and pale green. Fusarium oxysporum has glococose texture mycelium which was whitish-cream with pale to bluish-violet reverse plate color; chlamydospores were abundant and usually single while Fusarium compacticum also had floccose texture with whitish-cream and deep-rose-red in plate reverse side. Chlamydisoires were abundant in clusters of rough golden yellow.

Our results show that the effect of garlic additive was reflected on the total number of fungi associated with the samples. The Laboratory prepared kulikuli treated with garlic (BUIKG) additive generally had the least total fungal incidence $(1.6 \pm 0.21)$ followed by the Laboratory prepared sample without garlic. (BUIK). It had 2.00 \pm 0.30 incidence; while Kaduna kulikuli appeared to have the highest occurrence of moulds and Sokoto had the least occurrence. The most frequently observed moulds were Aspergillus flavus and Aspergillus parasiticus which are well associated with aflatoxin productions while the least frequently observed were $A$. fumigatus and $F$. compaticum (Table 2 ).

Table-2: Descriptive Summary of Mould Prevalence in the Kulikuli samples

\begin{tabular}{|c|c|c|c|}
\hline Fungal strain (N & Sample Location & \\
\hline (C) 2020 Scholars Academic Journal of Biosciences | Published by SAS Publishers, India & 273 \\
\hline
\end{tabular}


Abdul-Lateef et al., Sch Acad J Biosci, September, 2020; 8(9): 269-277

\begin{tabular}{|c|c|c|c|c|c|c|c|c|c|}
\hline$=106)$ & Sokoto & Abuja & Kano & Kaduna & Zamfara & BUIK & BUIKG & $\begin{array}{l}\text { Total } \\
\text { Incidence }\end{array}$ & $\begin{array}{l}\% \\
\text { Incidence }\end{array}$ \\
\hline Aspergillus flavus & 5 & 5 & 5 & 5 & 5 & 2 & 1 & 28 & 26.42 \\
\hline A. parasiticus & 5 & 4 & 5 & 5 & 5 & 1 & 1 & 26 & 24.58 \\
\hline A. tamarii & 3 & 2 & 1 & 1 & 1 & 1 & - & 9 & 08.49 \\
\hline A. niger & 1 & 1 & 2 & 1 & - & 1 & 1 & 7 & 06.60 \\
\hline A. fumigatus & - & - & - & 3 & - & - & - & 3 & 02.83 \\
\hline $\begin{array}{l}\text { Penicillium } \\
\text { oxalicum }\end{array}$ & 1 & 1 & 3 & 2 & 4 & - & - & 11 & 10.38 \\
\hline P. chrysogenum & - & 2 & - & 2 & 1 & 1 & - & 6 & 05.66 \\
\hline $\begin{array}{l}\text { Fusarium. } \\
\text { compaticum }\end{array}$ & - & - & 2 & 1 & 1 & 1 & 1 & 6 & 05.66 \\
\hline F. oxysporium & 2 & 3 & 2 & 1 & 1 & 1 & - & 10 & 09.43 \\
\hline Total & 17 & 18 & 20 & 21 & 18 & 8 & 4 & 106 & 100.00 \\
\hline Mean \pm SD & $\begin{array}{l}2.65 \pm 1 . \\
73\end{array}$ & $\begin{array}{l}3.17 \pm 2 \\
.03\end{array}$ & $\begin{array}{l}3.60 \pm 2 . \\
64\end{array}$ & $3.95 \pm 2.80$ & $3.00 \pm 2.14$ & $\begin{array}{l}2.00 \pm 0 \\
.30 \\
\end{array}$ & $1.6 \pm 0.21$ & & \\
\hline
\end{tabular}

Values are Mean of three replicates \pm Standard Deviation; BUIK $=U I$ Kulikuli; $B U I K G=U I$ Kulikuli with Garlic

\section{Nutrient Composition of Studied kulikuli}

There were significant differences $(\mathrm{P} \leq 0.05)$ between the nutrient content of market samples and the laboratory prepared samples. The BUIKG and BUIK were richer in food value when compared to the market samples across the states (Table 3). The highest crude protein content was detected in BUIKG $(59.23 \pm 1.43 \%)$ and BUIK $(50.23 \pm 1.40 \%)$ respectively; while about 45-50\% crude protein was recorded in the samples from all the selected states. The percentage moisture content in kulikuli was found to range between $10.96 \%$ and
$12.75 \%$ in the states. BUIK and Zamfara had the highest with $12.64 \pm 0.51 \%$ and $11.91 \pm 0.78 \%$ respectively; while the least was recorded in BUIKG $(6.64 \pm 0.66 \%)$. The highest crude fat was recorded in Kaduna samples $(4.826 \pm 0.19 \%)$ while BUIKG had the least $(3.26 \pm 0.37$ $\%)$. Highest Ash content was in BUIKG samples $(4.84 \pm 0.21 \%)$ and BUIK samples $(4.84 \pm 0.27)$; while Abuja samples had the least $(2.885 \pm 0.42 \%)$. The value of crude fat ranged between $2.6 \%$ and $3.4 \%$ with the BUIKG and BUIK having the highest values. $\mathrm{pH}$ value ranged between 5.96 to 6.88

Table-3: Comparative Proximate Analysis of Kulikuli from Different States

\begin{tabular}{|l|l|l|l|l|l|l|l|}
\hline & Zamfara & Kaduna & Sokoto & Abuja & Kano & BUIK & BUIKG \\
\hline $\mathrm{pH}$ & $6.34 \pm 0.31 \mathrm{~b}$ & $6.24 \pm 0.32 \mathrm{~b}$ & $6.14 \pm 0.42 \mathrm{~b}$ & $5.96 \pm 0.18 \mathrm{~b}$ & $5.97 \pm 0.18 \mathrm{~b}$ & $6.84 \pm 0.34 \mathrm{a}$ & $6.88 \pm 0.13 \mathrm{a}$ \\
\hline $\begin{array}{l}\text { \% Crude } \\
\text { protein }\end{array}$ & $46.31 \pm 0.19 \mathrm{~b}$ & $48.37 \pm 0.62 \mathrm{~b}$ & $49.23 \pm 1.40 \mathrm{~b}$ & $43.18 \pm 9.44 \mathrm{c}$ & $46.41 \pm 0.78 \mathrm{~b}$ & $50.23 \pm 1.40 \mathrm{a}$ & $59.23 \pm 1.43 \mathrm{a}$ \\
\hline \% Fat & $3.888 \pm 0.19 \mathrm{~b}$ & $4.826 \pm 0.19 \mathrm{a}$ & $4.448 \pm 0.14 \mathrm{a}$ & $4.636 \pm 0.21 \mathrm{a}$ & $4.546 \pm 0.14 \mathrm{a}$ & $3.826 \pm 0.21 \mathrm{~b}$ & $3.26 \pm 0.37 \mathrm{~b}$ \\
\hline $\begin{array}{l}\text { \% Crude } \\
\text { Fibre }\end{array}$ & $3.051 \pm 0.37 \mathrm{~b}$ & $3.018 \pm 0.26 \mathrm{~b}$ & $2.990 \pm 0.60 \mathrm{c}$ & $3.139 \pm 0.60 \mathrm{~b}$ & $3.202 \pm 0.31 \mathrm{~b}$ & $4.051 \pm 0.47 \mathrm{a}$ & $4.55 \pm 0.30 \mathrm{a}$ \\
\hline \% Ash & $2.948 \pm 0.43 \mathrm{c}$ & $3.074 \pm 0.29 \mathrm{~b}$ & $3.842 \pm 0.21 \mathrm{~b}$ & $2.885 \pm 0.42 \mathrm{c}$ & $3.911 \pm 0.15 \mathrm{~b}$ & $4.84 \pm 0.27 \mathrm{a}$ & $4.84 \pm 0.21 \mathrm{a}$ \\
\hline $\begin{array}{l}\text { \% Moisture } \\
\text { content }\end{array}$ & $11.91 \pm 0.78 \mathrm{a}$ & $11.37 \pm 0.76 \mathrm{a}$ & $10.64 \pm 0.52 \mathrm{~b}$ & $10.64 \pm 0.51 \mathrm{~b}$ & $8.876 \pm 0.39 \mathrm{c}$ & $12.64 \pm 0.51 \mathrm{a}$ & $6.64 \pm 0.66 \mathrm{~d}$ \\
\hline
\end{tabular}

Values are Mean of three replicates \pm Standard Deviation; Means \pm Standard Deviation have the same alphabet letter in the same row are not significantly different according to Duncan Multiple Range Test (DMRT) at differences (P $\leq 0.05)$. BUIK = Botany UI kulikuli; BUIKG = Botany UI Kulikuli with Garlic.

Effect of location and aflatoxigenic fungi on the $\mathrm{pH}$ of kulikuli samples is shown in Figure 2. It is evident that all the sampled kulikuli had $\mathrm{pH}$ levels lower than 7.0 indicating that kulikuli is an acidic snack. 


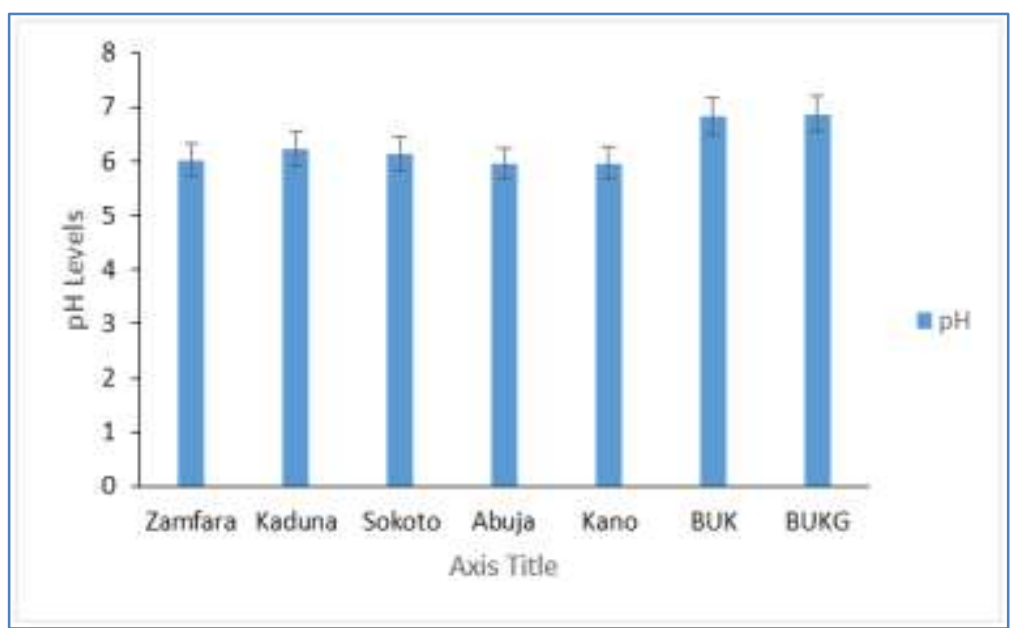

Fig-2: Effect of garlic additive on the pH level of the market and laboratory kulikuli samples; BUIK = Laboratory prepared Botany UI Kukuli without garlic additive; BUIKG = Laboratory prepared Botany UI Kukuli with garlic additive

\section{Aflatoxins contents of kulikuli}

There were varying proportions of Aflatoxins B1, B2, G1 and G2 in the samples (Fig. 2). It was observed that no samples contained aflatoxin concentration that was higher than the tolerance limit of $2 \mu \mathrm{g} / \mathrm{kg}$ except Zamfara state samples which recorded
$2.13 \mu \mathrm{g} / \mathrm{kg}$. Generally, aflatoxins B2 and B1 appeared to be the most prevalent aflatoxins while aflatoxins $\mathrm{G} 1$ and G2 appeared to be the least prevalent. The highest incidence of aflatoxins was recorded in the kulikuli samples with A. flavus and A. parasiticus; which makes them the major aflatoxigenic fungal strains.

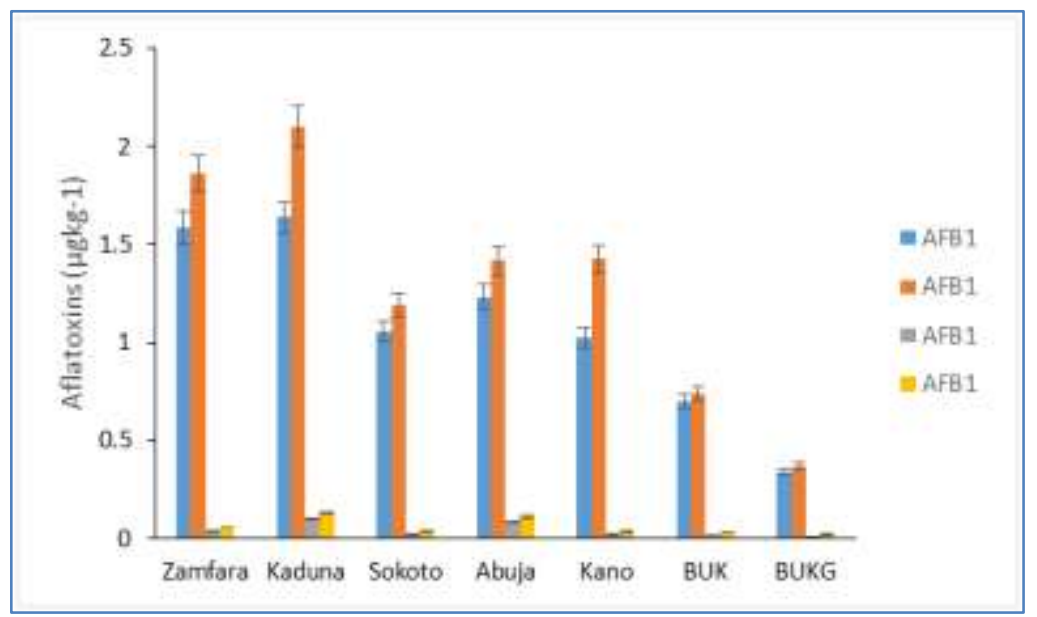

Fig-3: Aflatoxins contents of the tested groundnut cake (kulikuli) samples in each locations

The presence of aflatoxigenic fungi and aflatoxin contents of kulikuli samples varied significantly between the garlic additive kulikuli and the market samples. Among the sampled states, Kaduna and Zamfara appeared to have the highest Aflatoxin $\mathrm{B}_{2}$ and $B_{1}$ respectively; while Kano recorded least aflatoxin with $1.025 \mu \mathrm{gkg}^{-1}$. Kaduna state had the highest aflatoxin $\mathrm{B}_{2}$ content of $2.101 \mathrm{gkg}^{-1}$, Zamfara had $1.862 \mu \mathrm{gkg}^{-1}$ while Kano, Abuja and Sokoto had 1.425, 1.417 and 1.188 $\mu \mathrm{gkg}^{-1}$ respectively. Highest aflatoxin $\mathrm{G}_{1}$ was recorded in Kaduna $(0.1000 \pm 0.02739)$ and lowest in Kano $(0.0200 \pm 0.00707)$ and Sokoto $\left(0.0200 \pm 0.010 \mu \mathrm{gkg}^{-1}\right)$. Aflatoxin $G_{2}$ was at its peak in Kaduna $(0.1320 \pm$ $\left.0.05215 \mu \mathrm{gkg}^{-1}\right)$ and lowest in Sokoto $(0.0380 \pm 0.00837$ $\left.\mu \mathrm{gkg}^{-1}\right)$ and Kano $\left(0.0380 \pm 0.00837 \mu \mathrm{gkg}^{-1}\right)$. In all, the garlic treated laboratory prepared kulikuli BUIKG had the least aflatoxin contents (Fig. 3).

\section{DISCUSSION}

In this study, kulikuli from Kano, Zamfara, Kaduna and Sokoto, and Abuja-FCT were compared (in terms of nutrient, fungi, and aflatoxin contents) with the laboratory prepared samples. All the samples were found to be rich in protein and other nutrients. This observation is in agreement with the report of Ntare et al. [10] and USDA, [25] who separately identified groundnuts as a protein rich food. The $\mathrm{pH}$ of all the tested samples was slightly lower than 7.0 suggesting that kulikuli is an acidic food. The laboratory prepared kulikuli was observed to record the lowest fungal and aflatoxin composition. They were also found to be the richest in food value as compared with the market purchased samples. This may be as a result of garlic with antifungal properties that was added to the laboratory prepared sample [18]. 
This study also reported nutrient composition of kulikuli from Nigeria. This is very important as Nigeria is listed as one of the major producers of groundnuts in the world. It was reported that raw and processed groundnuts could be easily exposed to aflatoxins due to possible fungal contamination of this food [22, 15, 26, 27]. Asemoloye et al. [23] reported that Aspergillus was the major source of mycotoxin contamination of snacks in Nigeria and Sub-Sahara Africa. This was also established in this study as we recorded highest incidence of $A$. flavus and $A$. parasiticus in all the market-purchased kulikuli samples across the studied states.

This study identified nine species of moulds in the kulikuli samples that were collected from five (5) states of Nigeria. The moulds include Aspergillus flavus, Aspergillus parasiticus, Aspergillu stamarii, A. niger, A. fumigatus, P. oxalicum, $P$. chrysogenum, $F$. oxysporum, and $F$. compaticum. Based on the percentage incidence, Aspergillus flavus and A. parasiticus were the most dominant fungal species associated with the studied kulikuli samples. Similar observation was made by Jimoh and Kolapo [28] and by Varga et al., [25].

Incidences of aflatoxigenic fungi in food products can result from the processing or storage methods employed. In this study, samples of kulikuli from Kaduna State appeared to have the highest occurrence of moulds while Sokoto had the least occurrence of moulds; this may be as a result of processing and handling procedures [22, 27].

The study shows that the effects of fungi on the nutrient and aflatoxin compositions of the kulikuli samples reduced significantly in the laboratory prepared samples with garlic as an additive. It is therefore suggested that garlic should be used for kulikuli production. In addition, the detected aflatoxins in the samples were below the tolerance limit. There were no adequate multi-aflatoxin analyses of this snack in Nigeria based on the economic challenge/literacy level of many producers. This situation may raise aflatoxin tolerance limit in the near future if the case is not addressed now.

\section{CONCLUSION}

This study affirms that protein is the major nutrient in kulikuli with $\mathrm{pH}$ range of $5.96-6.88$. It was also observed that $A$. flavus and A. parasiticus were the major aflatoxigenic fungal strains associated with the sampled kulikuli across all the states. Detected aflatoxin contents of the samples were generally below the tolerance limit and aflatoxins $\mathrm{B}_{2}$ and $\mathrm{B}_{1}$ appeared to be the most prevalent. Specifically, garlic additive and the hygienic preparation were observed to significantly reduce the incidence of fungi and aflatoxin contamination of the kulikuli samples and also improved the nutrient concentration.
More detailed studies are however still needed for continuous detection and monitoring of aflatoxigenic agents in different Nigerian foods. The preliminary information obtained in this study indicates that there is a need for a more systematic and regular evaluation of the occurrence of both aflatoxins and toxigenic A. flavus strains in groundnuts in the studied areas as well as the processing methods adopted for the preparation of kulikuli. It is suggested that the production of kulikuli should be carried out under standard hygienic procedures, including storage and selling methods with the addition of garlic. Adequate quality control unit needs to be reactivated to assess the quality of the groundnuts from which groundnut cake and other products are made. Farmers' association and extension agents should also be encouraged to create awareness about aflatoxins, and dangers surrounding the commercialization and consumption of mouldy foods.

\section{REFERENCES}

1. Jonathan SG, Esho EO. Fungi and aflatoxin detection in two stored oyster mushrooms (Pleurotus ostreatus and Pleurotus pulmonarius) from Nigeria. Electronic Journal of Environmental, Agricultural \& Food Chemistry. 2010 Dec 1;9(11).

2. Asemoloye MD, Jonathan SG, Saddaf R, Habiba Z, Okoawo EE, Bello TS. Incidence and chemical Implications of aflatoxin in streetvended foods. Aflatoxin-Control, Analysis, Detection and Health Risks, ed. L. Abdulra'Uf,(London: IntechOpen Limited). 2017 Aug 30:153-76.

3. Jonathan G, Ajayi I, Omitade Y. Nutritional compositions, fungi and aflatoxins detection in stored gbodo (fermented Dioscorea rotundata) and elubo ogede (fermented Musa parasidiaca) from South western Nigeria. African Journal of Food Science. 2011 Feb 28;5(2):105-10.

4. Jonathan SG, Abdul-Lateef MB, Olawuyi OJ, Oyelakin AO. Studies on bio-deterioration, aflatoxin contamination and food values of fermented, dried and stored Ipomoea batatas chips. Nature and Science. 2012;10(11):123-8.

5. Jonathan SG, Abdul-Lateef N, Hull A, . Chikwem J, Asemoloye M, Odeseye A. Characterization and detection of aflatoxigenic genes in fungi associated with kulikuli (groundnut cake) from Nigeria. IHE: Lincoln University Journal of Science. 2019. 8: 1-13

6. Makun HA, Anjorin ST, Moronfoye B, Adejo FO, Afolabi OA, Fagbayibo G, Balogun BO, Surajudeen AA. Fungal and aflatoxin contamination of some human food commodities in Nigeria. African Journal of Food Science. 2010 Apr 30;4(4):127-35.

7. Olayiwola IO, Oganah BC, Oguntona CR, Popoola AR, Sanni SA, Sam-Wobo SO. Status of aflatoxin and anti-nutritional contents of standardized maize-based dishes/snacks consumed in Nigeria. Discourse Journal of Agriculture and Food Sciences. 2013;1(5):93-6. 
8. Jonathan GS, Ogunsanwo OB, Asemoloye MD. Analysis of Nutrient, Fungal and Aflatoxin Compositions of Ogi Processed with Stored and Fresh Maize. J Food Process Technol. 2018;10(773):2.

9. Kumar BS, Shankar SR, Vasanthi RP, Vishnuvardhan KM, Purushothan M. Comparative physico-chemical, proximate and mineral analysis on raw and roasted seeds of groundnut. Communications in Plant Sciences. 2013;3(3-4):25-9.

10. Naraian R, Sahu RK, Kumar S, Garg SK, Singh CS, Kanaujia RS. Influence of different nitrogen rich supplements during cultivation of Pleurotus florida on corn cob substrate. The Environmentalist. 2009 Mar 1;29(1):1.

11. Jonathan. Fungi Here, Fungi There, Fungi Everywhere: Unique and Unparalleled Contributions of Fungi to Environment, Food Production and Medicine-. Inaugural lecture. University of Ibadan. Ibadan. Nigeria.2019.

12. Young CT, Hammons RO. Variations in the protein levels of a wide range of peanut genotypes (Arachis hypogaea L.). Oleagineux. Oleaginous, 28: 293-297 1973.

13. Kayode AA, Kayode OT, Odetola AA. Telfairia occidentalis ameliorates oxidative brain damage in malnorished rats. International Journal of Biological Chemistry. 2010;4(1):10-8.

14. Adebesin AA, Saromi OT, Amusa NA, Fagade SO. Microbiological quality of some groundnut products hawked in Bauchi, a Nigerian City. Journal of food technology in Africa. 2001;6(2):53-5.

15. Jonathan SG, Abdul-Lateef MB, Ayansina AD. Fungal and aflatoxin detection in fresh and stored 'garri ijebu'(locally processed food). Report and Opinion. 2013;5(2):13-9.

16. Aletor $\mathrm{O}$ and Ojelabi A. Functional Attributes of Traditional Snacks and Oil Seed Cakes. Pakistan Journal of Nutrition. 2015; 6, 99-103.

17. Onyeagba RA, Ugbogu OC, Okeke CU, Iroakasi O. Studies on the antimicrobial effects of garlic (Allium sativum Linn), ginger (Zingiber officinale Roscoe) and lime (Citrus aurantifolia Linn). African Journal of Biotechnology. 2004;3(10):552-4.

18. Satish S, Mohana DC, Ranhavendra MP, Raveesha KA. Antifungal activity of some plant extracts against important seed borne pathogens of Aspergillus sp. Journal of Agricultural technology. 2007 Jan 1;3(1):109-19.

19. Mellon JE, Cotty PJ, Dowd MK. Aspergillus flavus hydrolases: their roles in pathogenesis and substrate utilization. Applied Microbiology and Biotechnology. 2007 Dec 1;77(3):497-504.

20. AOAC. Official Methods of Analysis. 15th Ed. Association of Official Analytical Chemists. Washington DC, USA.2008.

21. Gbolagade J, Ajayi A, Oku I, Wankasi D. Nutritive value of common wild edible mushrooms from southern Nigeria. Global Journal of Biotechnology and Biochemistry. 2006;1(1):16-21.

22. Jonathan SG, Olowolafe TB. Studies on nutrient contents and microorganisms associated with 'Dodo Ikire', a plantain snack from Western Nigeria. NISEB Journal. $2019 ; 1(1)$.

23. Jonathan SG, Adeniyi MA, Asemoloye MD. Fungal biodeterioration, aflatoxin contamination, and nutrient value of "suya spices". Hindawi Scientifica 2016:1-6 \%.

24. Oluwafemi F, Ibeh IN. Microbial contamination of seven major weaning foods in Nigeria. Journal of health, population, and nutrition. 2011 Aug;29(4):415.

25. USDA, 2012. USDA national nutrient database for standard reference, release 18. [Internet] U.S. Department of Agriculture, Agricultural Research Service, Nutrient Data Laboratory, Beltsville Md, United States.2012.

26. Atanda O, Makun HA, Ogara IM, Edema M, Idahor KO, Eshiett ME, Oluwabamiwo BF. Fungal and mycotoxin contamination of Nigerian foods and feeds. Mycotoxin and food safety in developing countries. 2013 Apr 68: 1455-1458

27. Janati SS, Beheshti HR, Asadi M, Mihanparast S, Feizy J. Preliminary survey of aflatoxins and ochratoxin A in dried fruits from Iran. Bulletin of environmental contamination and toxicology. 2012 Mar 1;88(3):391-5.

28. Jimoh KO, Kolapo AL. Mycoflora and aflatoxin production in market samples of some selected Nigerian foodstuffs. Research Journal of Microbiology. 2008;3(3):169-74. 